\title{
The sales effect of in-store product displays: The special case of total product relocation
}

\author{
Daniel Weimar \\ University of Duisburg-Essen \\ Mercator School of Management, Germany \\ Christian Deutscher \\ Department of Psychology and Sport Science \\ Bielefeld University, Germany \\ Reinhold Decker \\ Department of Business Administration and Economics \\ Bielefeld University, Germany
}

Keywords

Real sales data; in-store product displays; product placement; replacement; economic relevance

\begin{abstract}
Purpose of the research: Special product displays are expected to increase sales of the products they contain. Opposite to the rich existing literature on the impact of product in-store displays, we investigate the case of total product relocation instead of using the display location as an additional sales spot (secondary location strategy).

Design/methodology: In our setting, products are fully taken off the usual shelf and put into special displays close to the checkout area. We use data from a field experiment conducted in 214 stores of a German perfumery chain, in which eight products were moved to an in-store display.

Results/findings: Compared to the control group, the treated products placed in display boxes show a statistically significant increase in sales. The precise effect differs markedly between the investigated products, ranging from $80 \%$ to $478 \%$. Accumulated sales increased by $217.69 €$ per week on average due to the installation of product displays. We can conclude that complete relocation, indeed, boosts sales, but the precise magnitude seems to be driven by factors not covered in this study.

Practical implications and Conclusions: Based on the product selection, the results seem transferable to both other perfumery stores as well as general supermarkets. However, given the low additional revenues, retailers must consider all the additional costs associated with the implementation of product displays such as the costs of installing and maintaining the display, the costs of removing tags and rearranging the former shelf, and any opportunity costs. If these costs do not exceed the estimated effect, then the installation could be of economic importance.
\end{abstract}

Corresponding author: Daniel Weimar

Email addresses for the corresponding author: daniel.weimar@uni-due.de

First submission received: $17^{\text {th }}$ August 2020

Revised submission received: $12^{\text {th }}$ September 2020

Accepted: $2^{\text {nd }}$ October 2020

\section{Introduction}

Understanding the determinants and economic importance of special product in-store displays (subsequently called "displays") is highly relevant from both an academic as well as a practitioner perspective. Recently, Mou et al. (2018) emphasized the importance of aisle management and display placement for store profitability. While marketing research primarily seeks an understanding of individual purchase decisions, retail store management attempts to optimize product placement through displays. Such displays are typically placed at the end of an aisle or close to the checkout area. They are qualified to boost impulse buying (Asuquo and Igbongidi, 2015; Rook, 1987; Yu and Bastin, 2010; Zhou and Wong, 2004). Such spontaneous purchase decisions in the checkout area are hardly the result of an extensive decision process (Ebster et al., 2006). Accordingly, displays are a classical tool for triggering sales of selected products from the regular assortment, especially at the checkout (Stern, 1962).

While past empirical literature on the relationship between sales and displays is rich, it primarily focuses on one scenario, namely, additional product placement (e.g., Chandukala et al., 2017; Chevalier, 
1975; Cunningham and Connor, 1968; van Heerde et al., 2004; Pires, 2016; Wilkinson et al., 1982). In this common "secondary location" setting, products are partially relocated to a display, while simultaneously being offered on the usual shelf. However, store managers also use total relocation for various reasons. The most common contexts for total relocation are 1) special offers for bundles of products, 2) special test/promotional offers, 3) the movement of event-related products (offered the whole year) to event displays such as those for Easter or Christmas, 4) a quick sale of a discontinued product to clear the shelf for another product, and 5) an attempt to increase sales of certain products (e.g., products with a high margin such as the store's own brands). While such a total relocation to the checkout area can attract additional purchases by customers waiting in line or induce spill-over effects among the products offered in the display, it could also potentially reduce sales since customers might avoid making a purchase when they cannot find the sought-after product at its usual place (Park et al., 1989). Therefore, it remains unclear whether a total relocation strategy leads to similar effects compared to partially/additional replacements, since no empirical test of such setting exists so far.

Based on the scarce empirical evidence on total product relocation, we were able to use a large set of point-of-sale (POS) scanner data from all 214 retail stores of a German perfumery and cosmetics chain to answer this question. POS data allows to determine a function of causal variables, such as product price, display activities, and feature advertising, on product sales and the profitability of marketing investments (Blattberg and Neslin, 1990). More precisely, we analyze eight weeks of sales data for eight products. These products were totally relocated into new display boxes near the checkout area after week four and sold at the same price as previously. The present scenario enables us to answer the following research question: How strong is the sales impact of in-store product displays in the case of total product relocation?

Difference-in-differences estimations show a statistically significant increase in unit sales for products relocated from their usual position on the shelf to displays in the checkout area, with increases in sales varying by product. We conclude that total product relocation into display boxes can boost sales statistically similar to secondary-location strategies, while store managers still have to consider the costs associated with total product relocation within the store.

\section{The Impact of In-Store Displays on Sales}

To embed our research in the line of literature, this chapter offers an overview on the sales impact of product displays in general, while it also explains and motivates the specific features of total product relocation.

\subsection{Sales Impact of In-store Product Displays}

Retailers aim to increase the number of purchases by special in-store product display boxes, price promotions, or a combination of the two. ${ }^{1}$ Both displays and price promotion have been investigated intensively in theoretical and empirical marketing research. Their potential to trigger impulse buying was discussed as early as 1962 by Stern, who determined the factors that presumptively influence impulse buying. According to Rook (1987, p. 191), impulse buying occurs "when a consumer experiences a sudden, often powerful and persistent urge to buy something immediately." For the year 1999, the Point of Purchase Advertising Institute (POPAI) found that a little more than half of all purchase decisions in Germany are not made prior to entering the store, but inside the store.

The intensive involvement of marketing research in this field of consumer behavior analysis is covered by several meta-analytic literature reviews (Amos et al., 2014; Kalla and Arora, 2011; Muruganantham and Bhakat, 2013). Recent research has increasingly focused on topics beyond such established research paths, capturing the influence of culture on impulse buying behavior (Kacen and Lee, 2002), impulse buying behavior in emerging markets (Mittal et al., 2015), or impulse buying behavior in online shopping (Chan et al., 2017; Lim and Yazdanifard, 2015). According to Inman et al. (2009), special product displays increase unplanned purchases by $40 \%$. Although impulse buying tendencies vary among individuals (e.g., due to different resources or normative evaluations; see Rook and Fisher, 1995 and Vohs and Faber, 2007) and may differ between product types (Jones et al., 2003), the basic impact of displays is pivotal to retailers with respect to space management. Recent research also suggests benefits of displays towards eco-friendly shopping behavior (Wang et al. 2020). Even the handedness seems important for product display arrangements (Gould, Goldsmith and Lee, 2020). Displays in the checkout area are primarily used to boost sales of products that are simultaneously offered in their usual location within the store. Zhang

${ }^{1}$ For a more detailed overview of instruments for retailer promotions, which distinguished between price promotions, supportive non-price promotions and true non-price promotions, see Gedenk et al. (2010). 
et al. $(2007$, p. 80$)$ pointed out that it has become a "standard promotional practice for retailers to arrange certain items near checkout points in efforts to entice consumers into impulse purchases." The exposed presentation of products at or around the checkout register implies increased attention from customers. Campo et al. (2000) agree that the allocation of store space can lead to a significant increase in overall chain profitability. Therefore, we expect a statistically positive impact of displays on the sales of products (Hoyer and MacInnis, 2004).

Promoting products through displays triggers the question about what kinds of monetary gains result from such measures. The importance of empirically evaluating the profitability of alternative shelf-space assignments, including displays, was discussed early in the literature (e.g., Anderson, 1979). Based on an empirical study of the cross-category effects of aisle and display placements, Bezawada et al. (2009) emphasized the significance of display decisions and provided empirical evidence of remarkable revenue gains. Breugelmans and Campo (2011) examined the effectiveness of displays in an online grocery store and observed that little is known about the determining factors behind sales.

\subsection{Total Relocation to In-store Product Displays}

Based on the prevailing assumption that displays boost sales, several studies have empirically investigated their impact over the last decades. We identified 21 studies that used an empirical approach to quantify the relation between displays and sales (see Table 1). The majority used data from grocery stores and supermarkets. Probably related to data disclosure, the average time lag between data collection and the date the research was published was 7.6 years. Fewer than half of the studies generated data from at least two stores, and the majority observed fewer than two products. In contrast with the high number of specific studies, only four studies used a field experimental design to uncover the impact of displays on sales, leaving room for further field experimental evidence. Among the 17 studies that did not use an experimental design, 13 used household/store panel data (e.g., Nielsen, IRI Group). Furthermore, four studies did not use real sales data. Among the four experimental studies, two used additional price promotions. Only five studies discussed the precise average effects of displays. Chevalier (1975) measured the highest average effect of 572\% (with price promotion), while Wilkinson et al. (1982) reported the second highest impact with $290 \%$ (no price promotion). ${ }^{2}$ Most of the studies used more than one product type and report noticeable effect differences between products.

While existing studies offer a large variety of different settings in which the impact of displays has been tested, to the best of the authors' knowledge, no study has investigated a complete temporary total relocation of products to a display so far. All existing studies measured the impact of placing products into additional displays (secondary location), while also offering the product on the regular shelf. This scenario seems to be the most common one. However, stores already use total relocation of products, especially near the checkout register, for various reasons. First, single units are often sold on special displays near the checkout, while the regular product (containing several single units) is available only on the regular shelf (e.g., sweets and small product samples). Second, special product bundles or promotional products (e.g., for a test period) might temporally be offered only on special displays and then be removed from the store after a certain period. 
Table 1: Literature overview: Published research considering the effect of special product displays

\begin{tabular}{|c|c|c|c|c|c|c|c|c|c|c|}
\hline Study/Authors & Year & Store Type & $\begin{array}{l}\text { Year of } \\
\text { Data } \\
\text { Collection }\end{array}$ & Stores & $\begin{array}{l}\# \\
\text { Products } \\
\text { Types }\end{array}$ & $\begin{array}{l}\text { Field } \\
\text { Experi- } \\
\text { ment }\end{array}$ & Real Sales & $\begin{array}{l}\text { Total } \\
\text { Relocation }\end{array}$ & $\begin{array}{l}\text { Price } \\
\text { Promo- } \\
\text { tion }\end{array}$ & $\begin{array}{l}\text { Average } \\
\% \text { Effect }\end{array}$ \\
\hline This paper & 2020 & Perfumery & 2014 & 214 & 7 & Yes & Yes & Yes & Yes & $217 \%$ \\
\hline Seiler, Yao & 2017 & Grocery & 2006 & 1 & - & No & Yes & No & No & - \\
\hline Hong, Misra, Vilcassim & 2016 & Grocery & 2007 & 5 & 2 & No & Yes & No & - & - \\
\hline Pires & 2016 & Grocery & 2006 & 23 & 1 & No & Yes & No & - & - \\
\hline Kacen, Hess, Walker & 2012 & Grocery & - & 1 & - & No & Yes & No & - & - \\
\hline Haans, Gijsbrechts & 2011 & Grocery & - & 103 & 4 & No & Yes & No & - & - \\
\hline Hultén, Vanyushyn & 2011 & Grocery & 2008 & - & - & No & No & No & - & - \\
\hline Inman, Winer, Ferraro & 2009 & Grocery & 1995 & 28 & - & No & No & No & - & - \\
\hline Bezawada et al. & 2009 & Supermarket & 1997 & 79 & 2 & No & Yes & No & No & - \\
\hline Van Heerde, Leeflang, Wittink & 2004 & Grocery & - & 52 & 4 & No & Yes & No & No & $116 \%$ \\
\hline Boatwright, Dhar, Rossi & 2004 & Grocery & - & 97 & 1 & No & Yes & No & - & - \\
\hline Erdem, Sun & 2002 & Grocery & 1994 & - & 2 & No & Yes & No & No & - \\
\hline Lemon, Nowlis & 2002 & Grocery & 1985 & 3 & 1 & No & Yes & No & Yes & - \\
\hline Narasimhan, Neslin, Sen & 1996 & Grocery & 1988 & 2400 & 108 & No & Yes & No & No & - \\
\hline Fader, Lodish & 1990 & Grocery & 1986 & 12 & 331 & No & Yes & No & - & - \\
\hline Abratt, Goodey & 1990 & Grocery & 1986 & 15 & 2 & No & No & No & - & - \\
\hline Kumar, Leone & 1988 & Retailer & - & 10 & 1 & No & Yes & No & No & - \\
\hline Gupta & 1988 & Grocery & 1982 & 1 & 1 & No & No & No & - & - \\
\hline Wilkinson, Mason, Paksoy & 1982 & Supermarket & 1978 & 1 & 4 & Yes & Yes & No & Yes & $290 \%$ \\
\hline Chevalier & 1975 & Supermarket & 1973 & 4 & 8 & Yes & Yes & No & No & $572 \%$ \\
\hline McClure, West & 1969 & Drug Store & 1967 & 8 & 1 & Yes & Yes & No & Yes & $20 \%$ \\
\hline Cunningham, Connor & 1968 & Supermarket & - & 8 & 1 & Yes & Yes & No & No & $57 \%$ \\
\hline
\end{tabular}

Note: “- "= no clear description in the paper 
Third, products related to special events (e. g., Easter, Christmas, New Year, and the start of the school year) are temporarily offered on special displays. While most of these products are offered only before the special event, other products are always offered in the store but are moved to special display locations in the time before the event. For instance, paint for coloring eggs is often offered year around; however, it is relocated to a special display in the time before Easter. Fourth, store managers might seek a quick sale of discontinued products to clear the former shelf position for new (and potentially more profitable) products or in case of a store reorganization. Fifth, products might be relocated to special instore displays to guide the attention of customers to products such as those that are purchased less frequently (but have high margins) or to cross-sales or spillover-sales. For instance, customers buying sunscreen could also be exposed to body spray if it is part of the display and might decide to buy both. Considering the latter scenario, the question arises of whether an increase in additional cross-sales or spill over-sales can compensate for foregone sales from the usual shelf. Losses could occur if customers do not find their intended product at the regular place and react with consumption avoidance or the purchase of substitutes (Park et al., 1989). According to our literature analysis, there is no existing empirical evidence on total relocation in connection with in-store displays thus we empirically investigate the total relocation scenario for the first time.

\section{Empirical analysis}

\subsection{Experimental Setting}

We make use of scanner data provided by a German perfumery and cosmetics retailing company. The retailer offers a wide range of cosmetic, perfumery, and body hygiene products. Moreover, the retailer usually had few displays in the stores and mostly used price promotion for specific product categories as a promotional tool. Using a display box near the checkout area had not been used previously. Starting in week 16 of 2013, weekly sales data was collected for eight weeks in all 214 stores. After week four of the observation period (week 20 in 2013), the retailer introduced in-store product displays in front of the checkout register simultaneously in every store (simple, transparent, multiproduct acrylic boxes with no fancy design). No such display boxes had existed previously, and the products sold out of the display boxes in the checkout area were temporarily removed from their usual place on the shelf, leading to a different experimental setting compared to past research (see Table 1). Our sample covers the sales data for eight products put into these displays as well as the accumulated sales of all other products in every store. Thus, we had information on the relocation, the product category, the prices, and the presentation (same boxes and location in every store). We are aware of the no-control design, as the experiment was planned by the company. This also comes in tandem with the possibility that the selected products were not randomly selected by the company. However, one might argue that this drawback in internal validity is partly substituted by a high external validity due to the large variety of stores, the simultaneous installation, the purchases, and the homogenous execution.

The eight single relocated products were one type of BODY SPRAY $(2.95 €$, part of a portfolio for 12 months), one type of HAND CREAM ( $1.95 €, 3$ months), one type of LIP GLOSS (7.95 €, 12 months), one type of MASCARA (10.95 €, 8 months), one type of NAIL POLISH (9.95 $€, 3$ months), two types of PERFUME (9.95 $€$ and $14.95 €$, both 3 months), and one type of SUNSCREEN ( $6.95 €, 5$ months). ${ }^{3}$ A pretest classified body spray, hand cream, and sunscreen as mainly utilitarian products, while the other products showed more hedonistic characteristics. ${ }^{4}$ Each display box contained all eight treated products. Prices were identical during the whole observation period to reduce further exogeneity (combining display and price promotion proves inefficient according to Lemon and Nowlis (2002)). Such a setting fits a pre-test/post-test design with a control group (products not moved) as sales were determined before and after the introduction of the in-store displays (Campbell and Stanley, 1963). ${ }^{5}$

3 Note that not all body sprays, lip gloss, etc., were relocated but only one of the SKUs. The chain offers a variety of different products in all categories.

4 Products can serve hedonic or utilitarian purposes, or both. Utilitarian products are typically bought after a thought-out purchase decision to fulfill functionality-related goals, while hedonic products are associated with the pursuit of pleasure and enjoyment (Bayley \& Nancarrow, 1998; Chitturi et al., 2008; Hirschman \& Holbrook, 1982). Exposed product placement in the checkout area is expected to enhance sales of hedonic products at a higher rate than the sales of utilitarian products (Kacen et al., 2012).

5 Using a pre-test/post-test design with a control group, we can forgo controlling for drivers of sales such as seasonality or weather as they impact sales independent of being sold out of a display box or from the shelf. This setting is superior to one where a fraction of stores installs display boxes since there is no need to ensure that the 


\subsection{Variables}

Raw sales information was provided as weekly sales per store in $€$ (SALES). Since data is missing in some cases, the data sample represents an unbalanced panel. Table 2 reports that an average store generated weekly sales of 5,509 $€$ with sales ranging between $0 €$ and $267,544 €$. While sales of the nontreated products $(N=1,704)$ range from $6,797 €$ to $267,543 €$ per week (mean $=40,668 €$ ), sales of the eight treated products $(N=10,917)$ are, not surprisingly, much smaller, ranging from $0 €$ to $577 €$ per week with a mean of $28.19 €$. Since SALES is a right skewed variable, we use the logarithm of SALES as the dependent variable (LN SALES) in the subsequent analysis. ${ }^{6}$

Table 2: Descriptive statistics $(\mathrm{N}=12,621)$

\begin{tabular}{llllll}
\hline \hline Variable & Item & Mean & SD & Min & Max \\
\hline SALES & Weekly $€$ sales & 5,509 & 17,415 & 0.00 & 267,544 \\
LN SALES & Log of SALES & 3.82 & 2.81 & 0.67 & 12.50 \\
TREATMENT WEEKS & 1=weeks of displays introduction & 0.50 & 0.50 & 0.00 & 1.00 \\
REPLACEMENT (RP) & 1=sales from replaced products & 0.86 & 0.34 & 0.00 & 1.00 \\
\hline VISITORS/100 & Store visitors per week (in 100s) & 44.66 & 34.00 & 6.65 & 310.13 \\
HOLIDAY & 1=week with five sales days & 0.44 & 0.50 & 0.00 & 1.00 \\
SHOPPING CENTER & 1=Store within a shopping center & 0.43 & 0.49 & 0.00 & 1.00 \\
SALES AREA/100 & Store size in m (in 100s) $_{\text {STATE }}^{\text {Federal state of store location }}$ & 2.79 & 1.90 & 0.70 & 13.80 \\
\hline \hline
\end{tabular}

Although we use a control group design (which generally eliminates most of the unobserved heterogeneity), we incorporate two time-variant and three time-invariant covariates for 1) robustness reasons and 2) to maximize variance explanation of sales. First, VISITORS/100 reflects the visitor inflow into the store, determined by a camera counting system (divided by 100 for interpreting purposes). On average, 4,466 visitors per week entered the stores. Irrespective of the display activities, we expect a positive correlation between visitors and sales. ${ }^{7}$ Second, HOLIDAY is a dummy variable taking the value of one if the week of observation had only five instead of six sale days due to a public holiday (e.g., May $1^{\text {st, }}$ Whit Monday, Ascension of Christ, and Corpus Christi in six states). A five-day week might actually lead to an increase in sales, assuming customers stockpile or take a day off in a week with a public holiday (Smith, 1999). Third, SHOPPING CENTER is time-invariant and indicates whether a store was located in a shopping center building or in a pedestrian zone. According to Table 2, $43 \%$ of the stores were located in a shopping center. Fourth, the time-invariant variable SALES AREA/100 (divided by 100 for interpreting purposes) indicates a store's size, ranging from very small (a minimum of $70 \mathrm{~m}^{2} \sim 753 \mathrm{sq}$. ft.) to large (a maximum of 1,380 $\mathrm{m}^{2} \sim 14,854$ sq. $\mathrm{ft}$.) with an average store size of about $280 \mathrm{~m}^{2} \sim 3,003 \mathrm{sq}$. $\mathrm{ft}$. Accordingly, the more time customers need to browse through the store to search for their planned purchase items, the more unplanned purchases they tend to make (Haans and Gijsbrechts, 2011; Kollat and Willett, 1967). Fifth, the time-invariant and nominal variable STATE contains information about the federal state where a store was located (out of 16 federal states in Germany).

The correlation matrix (Table 3) draws attention to some variables that correlate quite highly, that is, SALES, VISITORS, and SALES AREA. Most importantly, the correlation between SALES and TREATMENT WEEKS is visibly larger for the treated products $(\mathrm{r}=0.01 \mathrm{vs} . \mathrm{r}=0.58)$, giving a first impression of the treatment effect. Therefore, the correlations between SALES and the other variables are smaller for the treated products as the treatment effect is the main driver of sales.

two groups (those who do and those who do not install display boxes) do not systematically differ from one another.

6 To calculate the logarithm without losing observations with zero sales per week, we added the minimum in sales for every product (in all cases, the price of the product) to all observations of the product as a constant.

7 However, additional visitors may result in overcrowding and longer lines in the checkout area, potentially enhancing purchasing activity in this area of the store. 
Table 3: Correlation matrix

$\begin{array}{llllll}1 & 2 & 3 & 4 & 5 & 6\end{array}$

Weekly $€$ SALES control

$\begin{array}{ll}\text { SALES } & 1.00 \\ \text { TREATMENT WEEKS } & 0.01 \\ \text { VISITORS/100 } & 0.77 \\ \text { HOLIDAY } & 0.05 \\ \text { SHOPPING CENTER } & 0.17 \\ \text { SALES AREA/100 } & 0.70 \\ \text { ly } € \text { SALES treated } & \\ \text { SALES } & 1.00 \\ \text { TREATMENT WEEKS } & 0.58 \\ \text { VISITORS/100 } & 0.10 \\ \text { HOLIDAY } & 0.00 \\ \text { SHOPPING CENTER } & 0.02 \\ \text { SALES AREA/100 } & 0.08\end{array}$

$\begin{array}{ll}1.00 & \\ 0.01 & 1.00 \\ 0.77 & -0.01 \\ 0.05 & -0.11 \\ 0.17 & 0.00 \\ 0.70 & 0.00 \\ & \\ 1.00 & \\ 0.58 & 1.00 \\ 0.10 & -0.01 \\ 0.00 & -0.09 \\ 0.02 & 0.00 \\ 0.08 & 0.00\end{array}$

1.00
-0.01
-0.11
0.00
0.00

1.00
-0.01
-0.09
0.00
0.00

$\begin{array}{lll}1.00 & & \\ 0.03 & 1.00 & \\ 0.18 & -0.01 & 1.00 \\ 0.79 & 0.00 & 0.06\end{array}$

1.00

Note: The lower correlation between store characteristics and sales in the treatment group is a result of the treatment which captures most of the variance.

\subsection{Estimation Strategy}

Given the pre-test/post-test design with a control group, we run difference-in-differences (DID) estimations, where the sales of products selected for the store displays are the treatment group, and the sales of all other (non-treated) products serve as the control group. This mitigates the potential problem of correlation between the treatment and other exogenous factors which affect both the control products well as the treated products (e.g. changes in the store, the city, the customers, or the weather). In contrast to our within-store treatment, a between store-treatment (varying the treatment of the eight products between stores), indeed, would have the advantage to explore an actual variation within the tested products. However, such a design would require a random selection of stores, which would probably lead to a reduction in the sample of stores (due to high coordination costs if all 214 stores should be treated specially). Such a reduction would increase the sample selection effect of stores into the treatment and rise random error effects associated with the selected stores. Therefore, from our point of view, a within-store treatment design containing every store should be as equally valid as between-store treatment design with a small sample of stores. To set up the DID structure, we generated the dummy variable TREATMENT WEEKS (TW), which equals one in weeks where the treated products were relocated from their regular positions on the shelf to the display boxes (weeks 20-23). In addition, REPLACEMENT (RP) is a dummy variable identifying the treated products. To capture the difference-in-difference effect (treatment effect), we generate an interaction term between TW and RP.

We present estimations with both store fixed effects and random effects. Fixed-effect models with store ID as the observation unit reduce unobserved time-invariant heterogeneity between stores. ${ }^{8}$ Since price, product category, presentation (same boxes in every store) and newness (replacement in every store) were identical in every week and every store (i.e. time and store invariance throughout the study period), these determinants had to be dropped from the models. In addition to the fixed-effect models, random effects estimations allow us to include the time-invariant but store-variant variables SHOPPING CENTER, SALES AREA/100, and STATE, all of which are excluded from the fixed-effect models. We run estimations for accumulative sales data for all products from the display as well as a separate analysis for each product. All models are estimated using robust standard errors (White, 1980). Since we use a loglevel design, the $\beta$-coefficients of continuous variables (VISITORS/100 and SALES AREA/100) can be interpreted as a $100 * \beta$ percentage change in SALES, when the explanatory variable is increased by one unit. For the dummy variables (TW, RP, Treatment effect TW\#RP, HOLIDAY, and SHOPPING CENTER), the estimated coefficients must be transformed first $\left(100^{*}\left(\mathrm{e}^{\beta}-1\right)\right)$ before achieving the percentage change in SALES (Halvorsen and Palmquist, 1980).

8 Mattila and Wirtz (2008) found staff friendliness to increase impulse buying. However, because our data covered only two consecutive four-week periods, we expected few personnel changes and a steady behavior from the staff throughout the observation period. 
While the random effects estimation also includes the time-invariant variables SHOPPING CENTER, SALES AREA, and STATE, the basic fixed effects estimation is specified as follows: ${ }^{9}$

\author{
LN WEEKLY $€$ SALES $=a_{0}+a_{1}$ TREATMENT WEEKS $+a_{2}$ REPLACEMENT $+a_{3}$ TREATMENT \\ WEEKS*REPLACEMENT $+a_{4}$ VISITORS $+a_{5}$ HOLIDAYS $+\varepsilon$
}

\title{
3.4 Results
}

The DID estimations with store fixed effects are presented in Table 4, while the random effect results are reported in Table 5. While model 1 covers the control group data as well as the sales data for all treated products (pooled regression), models 2 to 8 focus on the impact of displays on sales for the product categories separately. The $\mathrm{R}^{2}$ within is very high, predominantly to the large spread in sales between the control group and the treatment group. In an attempt to adjust the $\mathrm{R}^{2}$ to a more appropriate measurement of the variance explanation, we generated the $\mathrm{R}^{2}$ for all models with a $\mathrm{z}$-score of sales ${ }^{10}$ as a dependent variable to reduce the spread between the control and the treatment group. These $\mathrm{R}^{2}$ values range between 0.31 and 0.48 (which is similar to the $\mathrm{R}^{2}$ reported by Kumar and Leone, 1988) in the fixed effect models and between 0.16 and 0.46 in the random effect models.

In the TREATMENT WEEKS, sales generally increased between 3.2\% and 1.8\% (Table 4). As depicted by the random effects model, this effect ranges between $1.7 \%$ and $2.7 \%$ (Table 5). This small increase is statistically significant with $p<0.001$. Most of the variance in LN WEEKLY SALES is explained by REPLACEMENT, which is statistically significant with $\mathrm{p}<0.001 .{ }^{11}$ The high negative coefficient reflects the large difference in sales between the treated products and all other products in the store.

\footnotetext{
9 Since we have no information about the product characteristics, product prices, and the time on the sales portfolio for the control group products, we cannot use this information for the treated products in the DID estimation.

10 Standardization on group and store level with MEAN $=0$ and SD $=1$.

11 Since the products placed in the display boxes account for only a very small portion of the product variety offered.
} 
Journal of Business and Retail Management Research (JBRMR), Vol. 15 Issue 1

Table 4: Difference-in-differences store FIXED EFFECTS regression

\begin{tabular}{|c|c|c|c|c|c|c|c|c|}
\hline \multirow[b]{2}{*}{ DV: LN WEEKLY $€$ SALES } & (1) & (2) & (3) & (4) & (5) & (6) & (7) & (8) \\
\hline & All & BODY SPRAY & $\begin{array}{l}\text { HAND } \\
\text { CREAM }\end{array}$ & LIP GLOSS & MASCARA & NAIL POLISH & PERFUM & SUNSCREEN \\
\hline \multirow[t]{3}{*}{ TREATMENT WEEKS (TW) } & 0.024 & 0.019 & 0.020 & 0.026 & 0.022 & 0.018 & 0.026 & 0.032 \\
\hline & $(0.005)$ & $(0.005)$ & $(0.005)$ & $(0.005)$ & $(0.005)$ & $(0.004)$ & $(0.004)$ & $(0.006)$ \\
\hline & {$[0.000]$} & {$[0.000]$} & {$[0.000]$} & {$[0.000]$} & {$[0.000]$} & {$[0.000]$} & {$[0.000]$} & {$[0.000]$} \\
\hline \multirow[t]{3}{*}{ REPLACEMENT (RP) } & -8.278 & -9.103 & -9.757 & -8.244 & -7.666 & -8.187 & -8.073 & -7.323 \\
\hline & $(0.033)$ & $(0.039)$ & $(0.041)$ & $(0.038)$ & $(0.041)$ & $(0.042)$ & $(0.036)$ & $(0.040)$ \\
\hline & {$[0.000]$} & {$[0.000]$} & {$[0.000]$} & {$[0.000]$} & {$[0.000]$} & {$[0.000]$} & {$[0.000]$} & {$[0.000]$} \\
\hline \multirow[t]{3}{*}{ TW\#RP } & 1.222 & 1.384 & 1.170 & 1.754 & 0.586 & 0.865 & 1.517 & 0.607 \\
\hline & $(0.015)$ & $(0.033)$ & $(0.031)$ & $(0.029)$ & $(0.027)$ & $(0.016)$ & $(0.027)$ & $(0.037)$ \\
\hline & [0.000] & {$[0.000]$} & {$[0.000]$} & {$[0.000]$} & [0.000] & {$[0.000]$} & {$[0.000]$} & {$[0.000]$} \\
\hline \multirow[t]{3}{*}{ VISITORS/100 } & 0.009 & 0.011 & 0.010 & 0.009 & 0.011 & 0.009 & 0.010 & 0.022 \\
\hline & $(0.001)$ & $(0.001)$ & $(0.001)$ & $(0.002)$ & $(0.001)$ & $(0.002)$ & $(0.001)$ & $(0.002)$ \\
\hline & {$[0.000]$} & {$[0.000]$} & {$[0.000]$} & {$[0.000]$} & {$[0.000]$} & {$[0.000]$} & {$[0.000]$} & {$[0.000]$} \\
\hline \multirow[t]{3}{*}{ HOLIDAY } & 0.087 & 0.030 & 0.036 & 0.110 & 0.052 & 0.033 & 0.094 & 0.052 \\
\hline & $(0.010)$ & $(0.013)$ & $(0.011)$ & $(0.012)$ & $(0.012)$ & $(0.010)$ & $(0.010)$ & $(0.016)$ \\
\hline & {$[0.000]$} & [0.019] & [0.001] & {$[0.000]$} & [0.000] & [0.001] & [0.000] & [0.002] \\
\hline \multirow[t]{3}{*}{ Constant } & 10.012 & 9.962 & 9.965 & 9.990 & 9.937 & 10.027 & 9.947 & 9.448 \\
\hline & $(0.054)$ & $(0.060)$ & $(0.068)$ & $(0.074)$ & $(0.064)$ & $(0.077)$ & $(0.057)$ & $(0.074)$ \\
\hline & {$[0.000]$} & {$[0.000]$} & {$[0.000]$} & {$[0.000]$} & {$[0.000]$} & {$[0.000]$} & {$[0.000]$} & {$[0.000]$} \\
\hline $\mathrm{N}$ & 12,621 & 3,340 & 2,826 & 3,297 & 2,842 & 2,650 & 4,648 & 3,242 \\
\hline R2 Within & 0.917 & 0.991 & 0.994 & 0.987 & 0.988 & 0.993 & 0.987 & 0.982 \\
\hline R2 with z-score as DV & 0.473 & 0.437 & 0.426 & 0.447 & 0.307 & 0.438 & 0.481 & 0.320 \\
\hline TREATMENT EFFECT & $239.4 \%$ & $299.1 \%$ & $222.2 \%$ & $477.8 \%$ & $79.7 \%$ & $137.5 \%$ & $355.9 \%$ & $83.5 \%$ \\
\hline
\end{tabular}

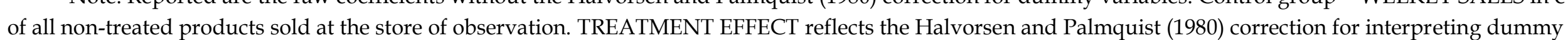

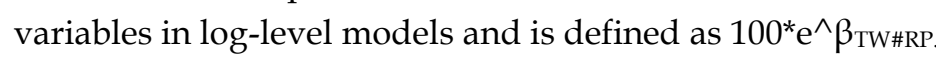


Table 5: Difference-in-differences store RANDOM EFFECTS regression

\begin{tabular}{|c|c|c|c|c|c|c|c|c|}
\hline DV: LN WEEKLY € SALES & $\begin{array}{l}\text { (9) } \\
\text { All }\end{array}$ & $\begin{array}{l}(10) \\
\text { BODY SPRAY }\end{array}$ & $\begin{array}{l}(11) \\
\text { HAND } \\
\text { CREAM }\end{array}$ & $\begin{array}{l}(12) \\
\text { LIP GLOSS }\end{array}$ & $\begin{array}{l}(13) \\
\text { MASCARA }\end{array}$ & $\begin{array}{l}(14) \\
\text { NAIL POLISH }\end{array}$ & $\begin{array}{l}\text { (15) } \\
\text { PERFUM }\end{array}$ & $\begin{array}{l}(16) \\
\text { SUNSCREEN }\end{array}$ \\
\hline \multirow[t]{3}{*}{ TREATMENT WEEKS (TW) } & 0.021 & 0.017 & 0.018 & 0.025 & 0.020 & 0.017 & 0.023 & 0.027 \\
\hline & $(0.005)$ & $(0.005)$ & $(0.005)$ & $(0.005)$ & $(0.005)$ & $(0.004)$ & $(0.005)$ & $(0.005)$ \\
\hline & {$[0.000]$} & {$[0.000]$} & [0.000] & {$[0.000]$} & {$[0.000]$} & {$[0.000]$} & {$[0.000]$} & {$[0.000]$} \\
\hline \multirow[t]{3}{*}{ REPLACEMENT (RP) } & -8.276 & -9.102 & -9.754 & -8.244 & -7.666 & -8.184 & -8.070 & -7.319 \\
\hline & $(0.033)$ & $(0.040)$ & $(0.040)$ & $(0.038)$ & $(0.041)$ & $(0.042)$ & $(0.037)$ & $(0.040)$ \\
\hline & {$[0.000]$} & {$[0.000]$} & {$[0.000]$} & {$[0.000]$} & {$[0.000]$} & {$[0.000]$} & {$[0.000]$} & {$[0.000]$} \\
\hline \multirow[t]{3}{*}{ TW\#RP } & 1.224 & 1.385 & 1.171 & 1.754 & 0.589 & 0.867 & 1.519 & 0.608 \\
\hline & $(0.015)$ & $(0.033)$ & $(0.031)$ & $(0.029)$ & $(0.027)$ & $(0.016)$ & $(0.027)$ & $(0.037)$ \\
\hline & {$[0.000]$} & {$[0.000]$} & {$[0.000]$} & {$[0.000]$} & {$[0.000]$} & {$[0.000]$} & {$[0.000]$} & {$[0.000]$} \\
\hline \multirow[t]{3}{*}{ VISITORS/100 } & 0.005 & 0.008 & 0.008 & 0.007 & 0.008 & 0.008 & 0.006 & 0.015 \\
\hline & $(0.001)$ & $(0.001)$ & $(0.001)$ & $(0.001)$ & $(0.001)$ & $(0.001)$ & $(0.001)$ & $(0.002)$ \\
\hline & {$[0.000]$} & {$[0.000]$} & {$[0.000]$} & {$[0.000]$} & {$[0.000]$} & {$[0.000]$} & {$[0.000]$} & {$[0.000]$} \\
\hline \multirow[t]{3}{*}{ HOLIDAY } & 0.095 & 0.036 & 0.041 & 0.115 & 0.058 & 0.035 & 0.102 & 0.071 \\
\hline & $(0.010)$ & $(0.012)$ & $(0.011)$ & $(0.011)$ & $(0.012)$ & $(0.009)$ & $(0.010)$ & $(0.017)$ \\
\hline & {$[0.000]$} & [0.003] & {$[0.000]$} & {$[0.000]$} & {$[0.000]$} & {$[0.000]$} & {$[0.000]$} & {$[0.000]$} \\
\hline \multirow[t]{3}{*}{ SHOPPING CENTER } & -0.002 & 0.030 & -0.019 & 0.011 & -0.016 & 0.009 & 0.000 & -0.110 \\
\hline & $(0.026)$ & $(0.037)$ & $(0.045)$ & $(0.032)$ & $(0.041)$ & $(0.047)$ & $(0.029)$ & $(0.056)$ \\
\hline & [0.951] & [0.423] & [0.677] & {$[0.725]$} & {$[0.701]$} & [0.855] & [0.987] & [0.048] \\
\hline \multirow[t]{3}{*}{ SALES AREA/100 } & 0.003 & 0.027 & 0.033 & 0.036 & 0.021 & 0.030 & 0.011 & -0.034 \\
\hline & $(0.010)$ & $(0.014)$ & $(0.013)$ & $(0.014)$ & $(0.013)$ & $(0.014)$ & $(0.012)$ & $(0.023)$ \\
\hline & {$[0.744]$} & [0.053] & [0.008] & [0.009] & [0.099] & {$[0.037]$} & {$[0.354]$} & [0.126] \\
\hline STATE Dummies & Incl. & Incl. & Incl. & Incl. & Incl. & Incl. & Incl. & Incl. \\
\hline \multirow[t]{3}{*}{ Constant } & 10.180 & 10.010 & 10.049 & 10.022 & 10.096 & 10.079 & 10.064 & 9.991 \\
\hline & $(0.058)$ & $(0.077)$ & $(0.077)$ & $(0.071)$ & $(0.073)$ & $(0.078)$ & $(0.070)$ & $(0.110)$ \\
\hline & {$[0.000]$} & {$[0.000]$} & [0.000] & {$[0.000]$} & {$[0.000]$} & {$[0.000]$} & {$[0.000]$} & [0.000] \\
\hline $\mathrm{N}$ & 12,621 & 3,340 & 2,826 & 3,297 & 2,842 & 2,650 & 4,648 & 3,242 \\
\hline R2 Within & 0.917 & 0.991 & 0.994 & 0.987 & 0.988 & 0.993 & 0.987 & 0.982 \\
\hline R2 with z-score as DV & 0.456 & 0.345 & 0.303 & 0.363 & 0.187 & 0.316 & 0.431 & 0.156 \\
\hline TREATMENT EFFECT & $240.1 \%$ & $299.5 \%$ & $222.5 \%$ & $477.8 \%$ & $80.2 \%$ & $138.0 \%$ & $356.8 \%$ & $83.7 \%$ \\
\hline
\end{tabular}

Note: Reported are the raw coefficients without the Halvorsen and Palmquist (1980) correction for dummy variables. Control group = WEEKLY SALES in $€$ of all non-treated products sold at the store of observation. TREATMENT EFFECT reflects the Halvorsen and Palmquist (1980) correction for interpreting dummy variables in log-level models and is defined as $100^{*} \mathrm{e}^{\wedge} \beta_{\mathrm{TWHRP}}-1$. 
In all the models, the interaction term (treatment effect) between time and treatment group dummy variables (TREATMENT WEEKS*REPLACEMENT) is statistically significant and positive with $p<0.001$. Moving products from the shelf and selling them from displays in the checkout area is associated with additional sales of $239.4 \%\left(100^{*} \mathrm{e}^{\wedge 1.224}-1\right)$ over all treated products. Models 2 to 8 report a variation between the treated products regarding the estimated treatment effect. The effect of completely relocating the products was largest for LIP GLOSS with an additional growth of $477.8 \%$ in sales. The second largest effect was detected for PERFUMES with a DID treatment effect of an additional $355.9 \%$, followed by BODY SPRAY $(+299.1 \%)$, and HAND CREAM (+222.2\%). The effect was smallest (but positive and statistically significant) for NAIL POLISH $(+137.5 \%)$, SUNSCREEN $(+83.5 \%)$, and MASCARA $(+79.7 \%)$. Using a random effects model with additional time-variant covariates (Table 5) changed the estimated treatment effects only marginally.

Besides the main (treatment) effect and store fixed effects, the variables VISITORS/100 and HOLIDAY are statistically significant $(\mathrm{p}<0.001)$ to explain variance within SALES and are positively correlated in both the fixed and random effects models (Tables 4 and 5). Regarding the time invariant variable SALES AREA/100, random effect estimations (Table 5) revealed some statistically significant $(p<0.01)$ effects (HAND CREAM, LIP GLOSS, NAIL POLISH, and BODY SPRAY) and some effects with higher p-values, suggesting that the assumption of any effect would cause an alpha-error with high probability (MASCARA, PERFUME, and SUNSCREEN). Sales seem to be affected only by a store's location (shopping center vs. pedestrian zone) when it comes to SUNSCREEN, leading to lower sales ($10.4 \%)$ in shopping center environments $(\mathrm{p}=0.048)$.

\section{Discussion}

With the research question in mind, our empirical results reveal clear sales benefits when completely relocating products to a display near the checkout. On average, sales of the relocated products increased by $239 \%$, which is somewhat close to the findings for products that were offered in a display in addition to their usual location in the store (Wilkinson et al., 1982; $+290 \%$ ). However, some products performed noticeably better than other products (see Table 6 for an overview). While sales of LIP GLOSS almost quintupled, revenues from SUNSCREEN and MASCARA did not even double. Such a large difference in sales between displayed products is in line with the past literature on second-location display replacements (Chevalier, 1975; Wilkinson et al., 1982). Looking at differences between the treated products (character, price, and time in portfolio), we cannot detect any clear pattern in explaining the differences in the treatment effect (Table 6). Thus, we can conclude that complete relocation, indeed, boosts sales, but the precise magnitude seems to be driven by factors not covered in this study, which gives room for future research.

Table 6: Summary of average weekly SALES per product category

\begin{tabular}{llllll}
\hline \hline Category & $\begin{array}{l}\text { Average } \\
\text { sales } \\
\text { before }\end{array}$ & $\begin{array}{l}\text { weekly } \\
\text { sales } \\
\text { after }\end{array}$ & $\begin{array}{l}\text { Average weekly } \\
\text { Price }\end{array}$ & Character & $\begin{array}{l}\text { Time } \\
\text { portfolio }\end{array}$ \\
\hline BODY SPRAY & $4.63 €$ & $19.29 €$ & $2.95 €$ & Utilitarian & 12 months \\
HAND CREAM & $2.20 €$ & $7.98 €$ & $1.95 €$ & Utilitarian & 3 months \\
LIP GLOSS & $9.46 €$ & $66.21 €$ & $7.95 €$ & Hedonistic & 12 months \\
MASCARA & $18.82 €$ & $32.87 €$ & $10.95 €$ & Hedonistic & 8 months \\
NAIL POLISH & $10.24 €$ & $26.21 €$ & $9.95 €$ & Hedonistic & 3 months \\
PERFUME & $11.58 €$ & $60.77 €$ & $9.95 € / 14.95 €$ & Hedonistic & 3 months \\
SUNSCREEN & $34.00 €$ & $56.79 €$ & $6.95 €$ & Utilitarian & 5 months \\
\hline
\end{tabular}

Note: Average weekly sales of the treatment group increased from $90.93 €$ to $270.12 €(197.07 \%)$. Average weekly sales of the control group increased from $40,559.09 €$ to $40,778.80 €(0.54 \%)$.

Following these results, the effect of additional (probably unplanned) sales of co-offered (and probably less frequently purchased) products in the display seems to compensate for potential losses in sales from customers who refrain from making a purchase when they do not find the sought-after product on its usual shelf (Inman et al., 2009). Based on the product selection, the results seem transferable to both other perfumery stores/chains as well as supermarkets. Regarding general drugstores and supermarkets, 
the product categories of hand cream, sun cream, and perfume are usually part of the sales portfolio and thus make the results of this study potentially applicable in these retail stores.

Although the estimations revealed statistically significant effects, the economic relevance should also be considered. To put the sales increase in perspective, we compare the average weekly sales of the eight products from the before-treatment time (90.93€) with the average weekly sales through the causallinked treatment effect $(90.93 \cdot 2.394=217.69 €)$. Thus, accumulated sales for the eight products increased by $126.76 €$ per week on average due to the installation of product displays. Given these additional revenues, retailers must consider all the additional costs associated with the implementation of product displays such as the costs of installing and maintaining the display, the costs of removing tags and rearranging the former shelf, and any opportunity costs. If these costs do not exceed the estimated effect, then the installation could be of economic importance.

\section{Conclusions}

This study empirically investigates the effect of a total relocation of products to an in-store product display near the checkout area using point-of-sale (POS) scanner data of eight cosmetic products. In our setting, these products were relocated from their usual shelf space and put into new display boxes. Using a field-experimental setting and data from 214 stores, the empirical results reveal causal and statistically significant increases in sales on average as well as for every single product. The impact ranges from increased sales of $79.7 \%$ to $478 \%$. Our findings confirm finding from past literature for settings where the products were placed in a special display but also remained on the shelf, as well.

However, as with most empirical studies, this study is not without limitations. First, due to the limited space in the checkout area of the participating retail stores along with some operational restrictions, the number of different products used in the field experiment was limited to eight. Future replications or continuations of this investigation might focus on other product categories with, presumptively, different purchasing patterns, such as sweets or home appliances. With regard to the generalization of the presented findings, future research should try to replicate the results for chains with an assortment of products different from the present one. Second, we do not have socio-demographic information about individual shoppers (such as age, sex, and profession), which is usually known in other studies on impulse buying (Dittmar et al., 1995; Luo, 2005; Wood, 1998). The inclusion of loyalty card information would reduce this problem but, in return, might result in a potentially non-representative sample because of the still limited coverage of customer relationship management systems in most countries, including Germany. Third, our data allowed us to test only to what extent in-store product displays lead to an increase in sales. However, no conclusion can be drawn as to why these displays induced additional demand, that is, what fraction of purchases out of special product displays is spontaneous vs. planned. Thus, future research could apply a multi-group design to test the effect of different presentation types (e.g., floor-based versus hanging display boxes and/or large versus small display boxes). Also measuring the impact of total product relocations to a store-within-store setting could be fruitful (Badrinarayanan \& Becerra, 2019). Fourth, we could not test for the relevance of several potentially interesting determinants such as price, product category, post-promotional dips, price levels, assortment structure of the retailer, depth of the used assortments, and presentation style since these characteristics were time- and store-invariant. Future research could include variations of these determinants to assess their strength of importance.

Acknowledgement: We acknowledge support for the publication costs by the German Research Foundation (DFG) and the Open Access Publication Fund of Bielefeld University. No other funding has been received. Conflict of Interest: We have no conflict of interest or any financial interest or benefit from or regarding the direct applications of our research.

\section{References}

Abraham, MM, Lodish, LM. (1987). Promoter: An automated promotion evaluation system. Marketing Science 6(2), 101-123.

Abratt, R, Goodey, SD. (1990). Unplanned buying and in-store stimuli in supermarkets. Managerial and Decision Economics 11(2), 111-121.

Amos, C, Holmes, GR, Keneson, WC. (2014). A meta-analysis of consumer impulse buying. Journal of Retailing and Consumer Services 21(2), 86-97.

Anderson, EE. (1979). An analysis of retail display space: Theory and methods. Journal of Business 52(1), 103-118. 
Asuquo, EE, Igbongidi, PB. (2015). Retail store merchandise assortment and display and their influence on consumer impulse buying behaviour in northwest Nigeria. Global Journal of Management and Business Research 15(6), 1-7.

Badrinarayanan, V, Becerra, EP. (2019). Antecedents and consequences of shoppers' attitude toward branded storewithin-stores: An exploratory framework. Journal of Business Research 105, 189-200.

Bayley, G, Nancarrow, C. (1998). Impulse purchasing: A qualitative exploration of the phenomenon. Qualitative Market Research: An International Journal 1(2), 99-114.

Bezawada, R, Balachander, S, Kannan, PK, Shankar, V. (2009). Cross-category effects of aisle and display placements: A spatial modeling approach and insights. Journal of Marketing 73(3), 99-117.

Blattberg, RC., Neslin, SA. (1990): Sales Promotion: Concepts, Methods, and Strategies, Englewood Cliffs, NJ: Prentice Hall.

Boatwright, P, Dhar, S, Rossi, PE. (2004). The role of retail competition, demographics, and account retail strategy as drivers of promotional sensitivity. Quantitative Marketing and Economics 2(2), 169-190.

Breugelmans, E, Campo, K. (2011). Effectiveness of in-store displays in a virtual store environment. Journal of Retailing 87(1), 75-89.

Campbell, TD, Stanley, CJ. (1963). Experimental and quasi-experimental designs for research. Chicago, IL: American Educational Research Association.

Campo, K, Gijsbrechts, E, Goossens, T, Verhetsel, A. (2000). The impact of location factors on the attractiveness and optimal space shares of product categories. International Journal of Research in Marketing 17(4), 255-279.

Chan, TKH, Cheung, CMK, Lee, ZWY. (2017). The state of online impulse-buying research: A literature analysis. Information \& Management 54(2), 204-217.

Chandukala, SR, Dotson, JP, Liu, Q. (2017). An assessment of when, where and under what conditions in-store sampling is most effective. Journal of Retailing 93(4), 493-506.

Chevalier, M. (1975). Increase in sales due to in-store display. Journal of Marketing Research 12(4), 426-431.

Chitturi, R, Raghunathan, R, Mahajan, V. (2008). Delight by design: The role of hedonic versus utilitarian benefits. Journal of Marketing 72(3), 48-63.

Cunningham, AC, O'Connor, NJ. (1968). Consumer reaction to retail price and display changes. European Journal of Marketing 2(2), 147-149.

Dittmar, H, Beattie, J, Friese, S. (1995). Gender identity and material symbols: Objects and decision considerations in impulse purchases. Journal of Economic Psychology 16(3), 491-511.

Ebster, C, Wagner, U, Neumüller, D. (2006). Mommy, I want that! - Spontaneous purchases triggered by children. In JC Andreani \& U Collesei (Eds.), Proceedings of the 5th International Congress of Marketing Trends, pp.1-28. Paris, France: Marketing Trends Association.

Erdem, T, Sun, B. (2002). An empirical investigation of the spillover effects of advertising and sales promotions in umbrella branding. Journal of Marketing Research 39(4), 408-420.

Fader, PS, Lodish, LM. (1990). A cross-category analysis of category structure and promotional activity for grocery products. Journal of Marketing 54(4), 52-65.

Gedenk, K., Neslin, SA., Ailawadi, KL. (2010). Sales promotion. In: Retailing in the 21st Century (pp. 393-407). Berlin, Heidelberg: Springer.

Gould, S, Goldsmith, E, Lee, M. (2020). The choice polarity effect: An investigation of evolutionary-based trait handedness and perceived magnitudes on laterally displayed choices. Journal of Business Research, https://doi.org/10.1016/j.jbusres.2020.02.004.

Gupta, S. (1988). Impact of sales promotions on when, what, and how much to buy. Journal of Marketing Research 25(4), 342-355.

Haans, H, Gijsbrechts, E. (2011). “One-deal-fits-all?" On category sales promotion effectiveness in smaller versus larger supermarkets. Journal of Retailing 87(4), 427-443.

Halvorsen, R, Palmquist, R. (1980). The interpretation of dummy variables in semilogarithmic equations. American Economic Review 70(3), 474-475.

Hirschman, EC, Holbrook, MB. (1982). Hedonic consumption: Emerging concepts, methods, and propositions. Journal of Marketing 46(3), 92-101.

Hong, S, Misra, K, Vilcassim, NJ. (2016). The perils of category management: The effect of product assortment on multicategory purchase incidence. Journal of Marketing 80(5), 34-52.

Hoyer, WD, MacInnis, DJ. (2004). Consumer behavior (3rd ed). Boston, MA: Houghton Mifflin.

Hultén, P, Vanyushyn, V. (2011). Impulse purchases of groceries in France and Sweden. Journal of Consumer Marketing 28(5), 376-384.

Inman, JJ, Winer, RS, Ferraro, R. (2009). The interplay among category characteristics, customer characteristics, and customer activities on in-store decision making. Journal of Marketing 73(5), 19-29.

Jones, MA, Reynolds, KE, Weun, S, Beatty, SE. (2003). The product-specific nature of impulse buying tendency. Journal of Business Research 56(7), 505-511. 
Kacen, JJ, Hess, JD, Walker, D. (2012). Spontaneous selection: The influence of product and retailing factors on consumer impulse purchases. Journal of Retailing and Consumer Services 19, 578-588.

Kacen, JJ, Lee, JA. (2002). The influence of culture on consumer impulsive buying behavior. Journal of Consumer Psychology 12(2), 163-176.

Kalla, SM, Arora, AP. (2011). Impulse buying - A literature review. Global Business Review 12(1), 145-157.

Kollat, DT, Willett, RP. (1967). Customer impulse purchasing behavior. Journal of Marketing Research 4(1), 21-31.

Kumar, V, Leone, RP. (1988). Measuring the effect of retail store promotions on brand and store substitution. Journal of Marketing Research 25(2), 178-185.

Lemon, KN, Nowlis, SM. (2002). Developing synergies between promotions and brands in different price-quality tiers. Journal of Marketing Research 39(2), 171-185.

Lim, PL, Yazdanifard, R. (2015). What internal and external factors influence impulsive buying behavior in online shopping? Global Journal of Management and Business Research 15(5), 1-9.

Luo, X. (2005). How does shopping with others influence impulsive purchasing? Journal of Consumer Psychology 15(4), 288-294.

McClure, PJ, West, EJ. (1969). Sales effects of a new counter display. Journal of Advertising Research 9(1), 29-34.

Mattila, AS, Wirtz, J. (2008). The role of store environmental stimulation and social factors on impulse purchasing. Journal of Services Marketing 22(7), 562-567.

Mittal S, Sondhi, N, Chawla, D. (2015). Impulse buying behaviour: An emerging market perspective. International Journal of Indian Culture and Business Management, 11(1), 1-22.

Mou, S, Robb, DJ, DeHoratius, N. (2018). Retail store operations: Literature review and research directions. European Journal of Operational Research 265(2), 399-422.

Muruganantham, G, Bhakat, RS. (2013). A review of impulse buying behavior. International Journal of Marketing Studies 5(3), 149-160.

Narasimhan, C, Neslin, SA, Sen, SK. (1996). Promotional elasticities and category characteristics. Journal of Marketing $60(2), 17-30$.

Park, CW, Iyer, ES, Smith, DC. (1989). The effects of situational factors on in-store grocery shopping behavior: The role of store environment and time available for shopping. Journal of Consumer Research 15(4), 422-433.

Pires, T. (2016). Costly search and consideration set in storable goods markets. Quantitative Marketing and Economics 14(3), 157-193. Point of Purchase Advertising Institute (POPAI) (Ed.) (1999): European Consumer Buying Habits Study, Frankfurt.

Rook, DW. (1987). The buying impulse. Journal of Consumer Research 14, 189-199.

Rook, DW, Fisher, RJ. (1995). Normative influences on impulsive buying behavior. Journal of Consumer Research 22(3), 305-313.

Seiler, S, Yao, S. (2017). The impact of advertising along the conversion funnel. Quantitative Marketing and Economics 15(3), 241-278.

Smith, MF. (1999). Urban versus suburban consumers: A contrast in holiday shopping purchase intentions and outshopping behavior. Journal of Consumer Marketing 16(1), 58-73.

Stern, H. (1962). The significance of impulse buying today. Journal of Marketing 26(2), 59-62.

Van Heerde, HJ, Leeflang, PS, Wittink, DR. (2004). Decomposing the sales promotion bump with store data. Marketing Science 23(3), 317-334.

Vohs, KD, Faber, RJ. (2007). Spent resources: Self-regulatory resource availability affects impulse buying. Journal of Consumer Research 33(4), 537-547.

White, H. (1980). A heteroskedasticity-consistent covariance matrix estimator and a direct test for heteroskedasticity. Econometrica: Journal of the Econometric Society 48(4), 817-838.

Wilkinson, JB, Mason, JB, Paksoy, CH. (1982). Assessing the impact of short-term supermarket strategy variables. Journal of Marketing Research 19(1), 72-86.

Wang, H., Shen, M., Song, YA., \& Phau, I. (2020). Do up-displayed eco-friendly products always perform better? The moderating role of psychological distance. Journal of Business Research 114(6), 198-212

Wood, M. (1998). Socio-economic status, delay of gratification, and impulse buying. Journal of Economic Psychology 19(3), 295-320.

$\mathrm{Yu}, \mathrm{C}$, Bastin, M. (2010). Hedonic shopping value and impulse buying behavior in transitional economies: A symbiosis in the mainland China marketplace. Brand Management 18(2), 105-114.

Zhang, X, Prybutok, VR, Strutton, D. (2007). Modeling influences on impulse purchasing behaviors during online marketing transactions. Journal of Marketing Theory and Practice 15(1), 79-89.

Zhou, L, Wong, A. (2004). Consumer impulse buying and in-store stimuli in Chinese supermarkets. Journal of International Consumer Marketing 16(2), 37-53. 